\title{
THE RIGHT OF PUBLICITY: A DOCTRINAL INNOVATION*
}

THE right of privacy, ${ }^{1}$ adopted by statute ${ }^{2}$ or judicial decision ${ }^{3}$ in twentytwo states, provides indirect protection of a person's commercial interest in his popularity. ${ }^{4}$ This doctrine generally allows an individual to enjoin and

*Haelan Laboratories v. Topps Chewing Gum Co., 202 F.2d SC6 (2d Cir. 1953).

1. On the right of privacy generally, see Warren \& Brandeis, Right to Pricacy, 4 Harv. L. Rev. 193 (1890) ; Green, The Right of Prizacy, 27 IL工 L. Rev. 237 (1932); Nizer, Right of Prizacy: A Half Centurry's Dezelopments, 39 MITCr. L. Rev. 526 (1941); Yankwich, The Right of Privacy, 27 Nome Dase LAw. 499 (1952).

2. N.Y. Civn Rights LAW $\$ \$ 50,51$ (1938); UTAB CODE Aws. \$76-4-\$ ct scq. (1953) ; VA. CODE ANr. $\$ 8-650$ (1950). The New York statute is typical:

"Any person whose name, portrait or picture is used within this state for advertising purposes or purposes of trade without the written consent first obtained ... may maintain an equitable action ... against the person ... so using ... to prevent and restrain the use thereof; and may also sue and recover damages for any injuries sustained by reasons of such use. ..."

Section 2(c) of the Federal-Trade Mark (Lanham) Act denies registration as trade symbols to names or pictures of persons whose consent has not been secured. 60 STAr. 423 (19.46), 15 U.S.C. $\$ 1052$ (c) (1946).

3. Peay v. Curtis Pub. Co., 78 F. Supp. 305 (D.D.C. 1948); Smith v. Doss, 251 Ala. 250, 37 So.2d 118 (1948); Reed v. Real Detective Pub. Co., 63 Ariz. 294, 162 P.2d 133 (1945) ; Mielvin v. Keed, 112 Cal. App. 285, 297 Pac. 91 (1931); Cason v. Easlin, 155 Fla. 198, 20 So.2d 243 (1944) ; Paresich v. New England AIut. L. Ins. Co., 122 Ga. 190, 50 S.E 68 (1905) ; Eick v. Perk Dog Food Co., 347 I1l. App. 293, 106 N.E.2d 742 (1952); Kunz v. Allen, 102 Kan. \&S3, 172 Pac. 532 (1918) ; Foster-Milburn Co. v. Chinn, 134 Ky. 424, 120 S.W. 364 (1909) ; Itzovich v. Whitaker, 115 La. 479, 39 So. 499 (1905); Pallas v. Crowley, Milner \& Co., 322 Mich. 411, 33 N.W.2d 911 (1948); Miartin v. Dorton, 210 Miss. 668, 50 So.2d 391 (1950) ; Munden v. Harris, 153 Mo. App. 652, 134 S.W. 1076 (1911) ; Welsh v. Pritchard, 241 P.2d $\$ 16$ (Mont. Sup. Ct. 1952); Bednarik: v. Bednaril:. 18 N.J. Misc. 633, 16 A.2d S0 (1940) ; Flaker v. Greensboro News Co., 212 N.C. 780, 195 S.E. 55 (1938) ; Friedman v. Cincinnati Local Joint Executive Ed., 20 Ohio Ops. 473 (1941); Hinish v. Meier \& Frank Co., 166 Ore. 4\$2, 113 P.2d 43S (1941); Clayman *. Bernstein, 38 Pa. D. \& C. 543 (1940). Cf. MIcCreery v. Miller's Groceteria Co., 99 Colo. 499 , 64 P.2d 803 (1936) (giving effect to right on theory of implied contract).

4. Prior to the birth of this right, the popularity of a famous person's name or picture, though of potential utility as an advertising device, rarely received legal protection. Ses, e.g., Clark v. Freeman, 11 Beav. 112, 50 Eng. Rep. 759 (1S48); Dockrell v. Duugall, 78 L.T. 840 (Q.B. 1898). Cf., Robertson v. Rochester Folding Box Co., 171 N.Y. 538, 64 N.E. 42 (1902). Where a person's likeness was painted or photographed, courts would imply a promise by the artist not to use the picture without the subject's consent. Moore v. Rugg, 44 Minn 28,46 N.W. 141 (1890); Pollard v. Photographic Co., 40 Ch. D. 345 (18SS) ; Stedall v. Houghton, 1S Times L.R. 126 (Ch. D. 1901). Sce Warren \& Brandeis, Right to Pricacy, + HARv. L. Rev. 193, 213 (1S90). More recently, some courts have use.l property rationale to accomplish the same resuit. E.g., Edison v. Edison Polyform \& Mfg. Co., 73 N.J. Eq. 136, 67 Atl. 392 (1907) ; Munden v. Harris, 153 Mo. App. 652, 134 S.W. 1076 (1911). Cf. Uproar Co. v. National Broadeasting Co., 8 F. Supp. 358 (D. Mass. 1934), aff'd, 81 F.2d 373 (1st Cir.), cirt. denicd, 298 U.S. 670 (1936). For criticism of this indirect approach to the right of privacy, see Nizer, Kight of Priacy: A Holf Confury's Developments, 39 Mircm. L. KEv. 526, 536 (1941). In all cases not involving an artist hired 
receive damages for the unauthorized commercial use of his name or likeness. ${ }^{5}$ But a famous person may prefer popularity with a price tag to protection from publicity. And, paradoxically, the threat of an action grounded upon the right of privacy may compel payment from advertisers for use of a name or picture. However, since the right of privacy was clesigned primarily to protect an individual's interest in being let alone, ${ }^{6}$ it is held to be personal ${ }^{7}$ and non-assignable. ${ }^{8}$ An advertising licensee is, therefore, unable to invoke the right of privacy to prevent use of the famous person's name or likeness by third parties. ${ }^{9}$

But the Court of Appeals for the Second Circuit, speaking through Judge Frank, recently held that an individual has, independent of the right of privacy, rights in his name or picture which can be granted to an exclusive licensee.10

by the subject, however, an individual ordinarily could not complain of unauthorized use of his name or picture in the absence of defamation, Burton v. Crowell Pub. Co., 82 F.2d 154 (2d Cir. 1936), or unfair competition, King Pharr Canning Operations v. Pharr Canlning Co., 85 F. Supp. 150 (W.D. Ark. 1949).

5. Pavesich v. New England Mut. L. Ins. Co., 122 Ga. 190, 50 S.E. 68 (1905) (damages); Brent v. Morgan, $221 \mathrm{Ky}, 765,299$ S.W. 967 (1927) (damages); Clayman v. Bernstein, $38 \mathrm{~Pa}$. D.\&C. 543 (1940) (injunction).

6. The "right to be let alone" was the phrase used by Warren and Brandeis in their pioneer article on the right of privacy, 4 HARv. L. REv. 193, 205 (1890). Stibsequent commentators have suggested that this phrase is too narrow to describe the totality of diverse interests protected by the right, contending that the right should be analyzed in terms of such personality interests as name, picture, life history, feeling, and emotions. Green, The Right of Privacy, 27 Ill. L. REv. 237 (1932). The phrase "interest in being let alone" is used here for lack of a better phrase to describe the totality of ways in which an individual may wish to protect himself from the public gaze, as opposed to a person's "commercial interest" in being paid for publicity.

7. See Wyatt v. Hall's Portrait Studio, 71 Misc. 199, 128 N.Y. Supp. 247 (Sup. Ct. 1911) ("The peculiarly personal character of the cause of action . . . negatives the idea that the legislature intended that it should be enforceable by the personal representatives of the person in whose favor the cause of action existed."); Von Thodorovich v. Franz Josef Beneficial Ass'n, 154 Fed. 911, 912 (C.C.E.D. Pa. 1907) (Consul of Austria not allowed to invoke right of privacy of his Emperor; relief granted on other grounds). Courts split on the question of whether an individual may invoke the right of privacy of a deceased relative to prevent publicity about that person. Compare Metter v. Los Angeles Examiner, 35 Cal. App.2d 304, 95 P.2d 491 (1939) (relief denied), voith Bazemore v. Savannah Hospital, 171 Ga. 257, 155 S.E. 194 (1930) (relief granted). But this question may be more realisticaliy viewed as involving the privacy interest of the living relative. See Nizer, The Right of Privacy: $A$ Half Century's Developments, 39 Micr. L. Rev. 526, 555 (1941).

8. Pekas Co. v. Leslie, 52 N.Y.L.J. 1864 (N.Y. Sup. Ct. 1915), 28 HARv. L. Rev. 689; cf. Hanna Mfg. Co. v. Hillerich \& Bardsky Co., 78 F.2d 763, (5th Cir. 1936). Sec Haelan Laboratories, Inc. v. Topps Chewing Gum Co., 202 F.2d 866, 867 (2d Cir. 1953).

9. See cases cited in note 8 supra.

10. Although the Second Circuit spoke only of photographs, the court probably intended the decision to apply to names as well. The reasons given by the court for recognizing the right, note 13 infra, justify protection of names as well as photographs. Further, the cases which the court cites in support of the right of publicity, note $14 \mathrm{infra}$, involved persons' names rather than pictures. 
In Haelan Laboratories v. Topps Chcwing Gum Co.11 a bubble gum manufacturer who had obtained contracts with big-league baseball players for the exclusive right to use their names and likenesses in connection with the sale of gum or candy sought to enjoin defendant who subsequently used these advertising devices in the promotion of its candy. ${ }^{12}$ Defendant had argued that the ball players possessed no legal interest in their photographs other than the right of privacy, which could not be assigned to plaintiff. But the court stated that, in addition to his privacy right, a man has a "right in the publicity value of his photograph, i.e., the right to grant the exclusive privilege of publishing his picture."13

11. 202 F.2d 866 (2d Cir. 1953).

12. Plaintiff had alleged in the district court that defendant had infringed plaintifi's common-law trade mark "Baseball" by using it on candy wrappers; that defendant was engaging in unfair competition by "passing off" its candy as that of plaintiffs; and that defendant had invaded rights given plaintiff by his exclusive contract with the players. The district court denied relief on all counts: it held that the name "baseball" vas generic, and could not be appropriated as a trade mark; that there was no prouf of consumers being deceived by the similarity in advertising; and that plaintiff's contracts with the players gave it no rights against third parties, on the theory that a nersonal name cannot be "assigned in gross." Bowman Gum v. Topps Chewing Gum Co., 103 F. Supp. 94 (E.D.N.Y. 1952). On appeal, the plaintiffs dropped their charges of trade mark infringement and unfair competition.

13. Haelan Laboratories v. Topps Chewing Gum Co., 202 IF 2d 866 (2d Cir. 1953). Judge Swan concurred only in so much of the opinion as dealt with defendant's liability for inducing breach of contract.

Haelan is the first case expressly to recognize a "right of publicity." The Second Circuit cited as authority Liebig's Extract of Meat Co. v. Liebig Extract Co., 18u lied. 688 (2d Cir. 1910), which held that the exclusive licensee of the name "Liebig" could prevent its use on competing products. But it is not clear whether the result is based on the exclusive contract, or on trade name infringement ductrine. Another ease which lays the foundation for the decision is Uproar Co. v. National Eroadeasting Co., $8 \mathrm{~F}$. Supp. 358 (D. Mass. 1934), aff'd, S1 F.2d 373 (1st Cir.), cert. devicd, 298 U.S. 070 (1936), where the court held a radio station had a "property right" in the name of a radio announcer with whom it had an exclusive contract. But that case can be distinguished from Haelan on the grounds that there the court placed great weight on the fact that the station had, through expenditure of time and money, created "good will" in the name, which a third party had appropriated. Two cases seem opposed to the right of publicity: Hanna Mffg. Co. v. Hillerich \& Bradsby Co., 78 F.2d 763 (5th Cir. 1936); and Pelias Co. v. Leslie, 52 N.Y.L.J. 1864 (N.Y. Sup. Ct. 1915). The Second Circuit chose not to fullow the Hanna case, and distinguished Pekas on the grounds that there the court's attention was drawn exclusively to the right of privacy, which it held non-assignable, and did not consider other rights which a person may have in his name or picture.

The Court gave no reason for recognizing the right of publicity other than that famous people would often receive no money for the use of their names and pietures unless they could grant a licensee protection against third parties. The cases which the Court cites in support of the right, Wood v. Duff-Gordon, 220 N.Y. SS, 118 N.E. 214 (1917) ; and Madison Square Garden v. Universal Pictures, 255 App. Div. 459, 465, 7 N.Y.S.2d 845, 851 (1st Dept. 1938), indicate that the Court felt it was following a legal "principle" of granting legal protection as "property" to "rights" which have acquired "pecuniary value." In the Madison Square Garders case the Court gave protection on 
This new right of publicity allows a licensee of a famous person adequate protection against third parties. Traditionally, direct action by the licensee against such parties was permitted where they had induced breach of the contract. ${ }^{14}$ And, in addition, use of a name or picture could be enjoined where continued use constituted trademark infringement. ${ }^{15}$ Otherwise the licensee's

such a theory to the owner of the Garden against defendant who falsely represented that movies were taken in the Garden Arena. And in Duff-Gordon, the court, in upholding a contract for the exclusive use of a person's name for advertising purposes, implied that such use had commercial value. Apparently the Second Circuit felt that Madison Square Garden plus Duff-Gordon equals the right of publicity.

The view that the law protects people against appropriation of values which they have created received impetus in the case of International News Service v. Associated Press, 248 U.S. 215 (1918), which gave plaintiff relief against defendant who copied news from plaintiff's bulletins and sold it to the public. While Haelan appears to approve of an extension of this doctrine, the Second Circuit previously held that the Neres Service case should be limited to the case of news. Cheney Bros. v. Doris Silk Corp. 35 F.2d 279 (2d Cir. 1929) ; R.C.A. v. Whiteman, 114 F.2d 86 (2d Cir. 1940). For discussion of possible circularity in the view that courts protect "rights which have pecuniary value," see Cohen, Transcendental Nonsense and the Functional Approach, 35 CoL. L. Rev. 809, 814-17 (1935).

In the principal case, the court indicated that the "right of publicity" may not have all the usual attributes of a "property right;" for it reserved the question whether and how far defendant would have been liable if he had no knowledge of plaintiff's contract.

14. Active inducement must be proved; mere proof that defendant entered into a contract the performance of which required a breach of plaintiff's contract is ustually not enough. Sweeney v. Smith, 167 Fed. 385 (C.C.E.D. Pa. 1909), aff'd, 171 Fed. 645 (3rd Cir.), cert. denied, 215 U.S. 600 (1909). But see Wade v. Culp, 107 Ind. App. 503, 23 N.E. $2 d$ 615 (1939). See, generally, Prosser, TORTS $\$ 104$ (1941); Harper, Interference with Contractual Relations, 47 N.U.L. REv. 873 (1953).

In the Haelan case, defendant had contracted with some of the players through its own agent. Here the court held that defendant would be liable for any breach of plaintiff's contracts thus induced. But defendant had also purchased from an independent party contract rights to use other of the players' names and pictures. Further, plaintiff alleged that defendant had used certain players' photographs and names without their consent. Here the rationale of inducement to breach was not available, but the court held that the right of publicity was applicable.

15. Societe Anonyme v. Pasteur Chamberland Co., 8 T.M. Rep. 298 (S.D. Ohio 1918); cf. King Pharr Canning Operations v. Pharr Canning Co., 85 F. Supp. 150 (W.D. Ark. 1949). See Callakan, Unfair Competition and Trade Marks, \$ 77.4(d) (2d ed. 1950); Niars, Unfair Competition and Trade Marks, c. VI (4th ed. 1947); Pike, Pcrsonal Names as Trade Symbols, 3 Mo. L. Rev. 93, 101 (1938).

The licensee might have an unfair competition action against a third party who falsely claims the indorsement of the licensor. Though false advertising is not generally regarded as a tort, Callman, False Advertising as a Competitive Tort, 48 CoL. L. REv. 876 (1948), the seller of a unique product has been granted relief against a competitor who falsely represented that his product had the qualities of plaintiff's on the theory that plaintiff, because of his monopoly position, was clearly damaged by defendant's action. Ely-Norris Safe Co. v. Mosler Safe Co., 7 F.2d 603 (2d Cir. 1925), rev'd on other grounds, 273 U.S. 132 (1927). On the same theory, perhaps a licensee who has obtained the "exclusive" indorsement of a famous person can prevent others from falsely claiming that person's indorsement. But cf. American Washboard v. Saginaw Mfg. Co., 103 Fed. 281 (Gth Cir. 1900). 
remedy had to be against his licensor..$^{16}$ And in all cases damages-presumably based on lost profits ${ }^{17}$-would be difficult to prove. ${ }^{18}$ The Haclan case appears to sidestep most of these difficulties. While the Second Circuit did not indicate what relief the right of publicity commands, the court suggeste.1 that an injunction, in addition to damages, might be "justified."10

But Haelan's right of publicity probably gives a famous person more than the right to assign a protectible interest in his name or picture. By allowing an individual to make a grant of the publicity value of his name or photograph, the Haelan case gave protection to persons' commercial interest in their personality independent of their privacy interest. In so doing, Haclan implied that such commercial interest, aside from any privacy: interest, might justify legal protection of an individual against unauthorized use of his name or picture. While a famous person can generally invoke the right of privacy against an advertiser who appropriates his name or picture without permission, ${ }^{-9}$ this right may not always afford adequate protection to his commercial interest in his personality. Celebrities complaining of the unauthorized use of their names or likenesses have sometimes been held, in effect, to have waived their right of privacy because they sought and received publicity in the past. 21 And where relief has been granted under the privacy doctrine it is not clear whether plaintiffs have recovered damages for injury to the commercial interest in their popularity. ${ }^{22}$ But if the publicity value of a famous person's name

16. Conceivably, the advertiser could require the licensor to promise to involse his right of privacy against a third party who uses his name or picture without the licensor's consent. But such a promise might be held unenforceable as encouraging litigation. Sce CoRBIn, Contracts \$ 1428 (1951). Moreover, the licensor might be held to have "waived" his right of privacy by consenting to the use of his name or picture for advertising in the first place. See cases cited note 22 infra.

17. Cf. Gonzales v. Rivera, 37 N.M. 562,25 P.2d 802 (1933) (allowing recurery for loss of profits resulting from breach of promise not to compete); Wood v. Pender-Dosey Grocery Co., 151 Va. 706, 144 S.E. 635 (1928) (same). For general discussion of damages, see 5 Corbin, Contracts $\$ 990$ et seq. (1941).

18. For discussion of methods and difficulty of proving loss of profit from breach of contract, see Note, 64 Hanv. L. Rev. 317 (1950). For problems of proof of loss of profits

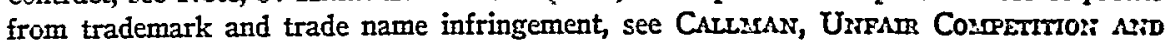
TRADE MARKS, $\$ \$ 9.3$ (1950).

19. Haelan Laboratories v. Topps Chewing Gum Co., 202 F.2d 866, 869 , 870 (2d Cir. 1953).

20. See cases cited in note 8 stipra.

21. O'Brien v. Pabst Sales Co., 124 F.2d 167 (5th Cir. 1941), ccri. desied, 315 U.S. 823 (1942) (football player denied injunction against use of picture in beer advertisement on grounds, isster alia, that by deliberately seeking wide publicity he had "ceased to be a private person"); Martin v. F.I.Y. Theatre Co., 10 Olio Ops. 338, 26 Ohio L Abs. 67 (1938) (relief denied to famous actress complaining of use of picture in advertising); Cf. Gautier v. Pro-Football, Inc., 304 N.Y. 354, 107 N.E.2d 485 (1952) (entertainer denied recovery for unauthorized, sponsored telecast of performance; concurring judge stated that right of privacy lost by public performance).

22. Harris v. H. S. Gossard Co., 194 App. Div. 68S, 185 N.Y. Supp. 861 (1st Dept. 1921) (actress who had received prior publicity and admitted that present advertising 
or picture is to be shielded without reference to the right of privacy, these celebrities will be fully protected: prior publicity will enhance rather than bar relief. They will be able to obtain an injunction or recover damages commensurate with the advertising value of their names or pictures. ${ }^{23}$

And the right of publicity may be extended beyond advertising cases. A famous person may wish to prevent appropriation of the public appeal of his personality by a telecast reproduction of his performance, ${ }^{24}$ a biography, ${ }^{25}$ or by use of his photograph for illustrating newspapers or magazines. ${ }^{26}$ Here, as in the advertising situation, the right of privacy has sometimes been considered waived because of plaintiff's past exposure in the public limelight, ${ }^{27}$ but this would not be a ground for denying relief under the right of publicity. And, where courts have sometimes held that plaintiff's privacy interest was out-

helped her, awarded six cents damages for unauthorized use of name and picture in advertising). Cf. Cason v. Baskin, 155 Fla. 198, 20 So.2d 243 (1944) (where plaintiff's character used in fictional novel, privacy complaint sustained, but claim to share in profits dismissed). But of. Gautier v. Pro-Football, Inc., 278 App. Div. 431, 438, 106 N.Y.S.2d 553, 560, aff'd, 304 N.Y. 354, 107 N.E.2d 485 (1952) (where animal trainer's performance televised without his consent, privacy complaint dismissed, but dicta that where plaintiff establishes cause of action for invasions of his privacy, he may recover for damage to his commercial interest as well) ; Redmond v. Columbia Pictures, Inc, 277 N.Y. 707, 14 N.E.2d 636 (1938) (professional golfer, whose trick shot exhibition displayed in a movie without his consent, awarded $\$ 1,500$ damages).

23. See discussion of this view in Spring, Risks and Rionts in Punlisuing, Etc. $\S \S 15,192$ (1952).

24. E.g., Gautier v. Pro-Football, 304 N.Y. 354, 107 N.E.2d 485 (1952); Peterson v. K.M.T.R. Radio Corp., 18 U.S.L. WeEk 2044 (Calif. Super. Ct. 1949) ; Chavez v. Hollywood Post No. 43, 16 U.S.L. Weer 2362 (Calif. Super. Ct. 1948).

25. E.g., Koussevitzky v. Allen, Towne \& Heath, 188 Misc. 479, 68 N.Y.S.2d 779 (Sup. Ct.), aff'd, 272 App. Div. 759, 69 N.Y.S.2d 432 (1st Dep't 1947) ; Jeffries v. New York Evening Journal Pub. Co., 67 Misc. 570, 124 N.Y. Supp. 780 (Sup. Ct. 1910).

26. E.g., Larhiri v. Daily Mirror, 162 Misc. 776, 295 N.Y. Supp. 382 (Sup. Ct. 1937); Molony v. Boy Comics Publishers, 277 App. Div. 166, 98 N.Y.S.2d 119 (1st Dep't 1950).

27. "[Plaintiff's] grievance here is not the invasion of his 'privacy'-privacy is the one thing he did not want or need in his occupation [as animal trainer]. His real complaint, but one we cannot redress in this suit . . . is that he was not paid for the telecasting of his show." Desmond, J., concurring in Gautier v. Pro-Football, 304 N.Y. 354, 361, 107 N.E.2d 485, 489 (1952). See also Peterson v. K.M.T.R. Radio Corp, 18 U.S.L. WeEK 2044 (Calif. Super. Ct. 1949) ; Chavez v. Hollywood Post No. 43, 16 U.S. L. Weer 2362 (Calif. Super. Ct. 1948).

It is possible that plaintiffs could have recovered in these cases had they involed unfair competition or property doctrine. See Pittsburgh Athletic Co. v. K.Q.V. Broadcasting Co., 24 F. Supp. 490 (W.D. Pa. 1938) (owner of ball park held to have at "property right" in the news value of the ball game; can control dissemination of reports of the game for reasonable time following the game); Metropolitan Opera Ass'n v. Wagner-Nichols Recorder Corp., 199 Misc. 786, 101 N.Y.S.2d 483 (Sup. Ct.), aff'd, 279 App. Div. 632, 107 N.Y.S.2d 795 (1st Dep't 1951) (opera company granted relief against unauthorized recording of opera on theory of unfair competition). But cf. National Exhibition Co. v. Teleflash, Inc., 24 F. Supp. 488 (S.D.N.Y. 1936) (owncr of ball park claiming unfair competition denied relief against unauthorized broadcast of 
weighed by the public's interest in news or information, ${ }^{\mathrm{S}}$ the balance may now swing in plaintiff's favor if both his privacy and publicity interests are considered. ${ }^{29}$

Haelan, however, does not decide whether the right of publicity protects only the commercial value of fame. If so limited, the right may afford incomplete relief in non-advertising cases. For a person's performance, life history, or photograph may have commercial value not only because of his fame, but also because of its inherent educational or entertainment value. But it is not likely that the Second Circuit intended to shield the value of fame alone; if this were the limit of Haelan's thrust, an unknown artist could not invole the right of publicity to protect his commercially valuable attributes. The "publicity value of his photograph"30 probably refers not merely to the advertising force of fame, but rather to the total potential advertising value of his name or likeness. Similarly, an unknown person's life story or performance may have "publicity value" in aiding the promotion of the book, magazine, or radio or television program in which it appears.

Even though courts may read the right of publicity as merely allowing a person to grant a protectible interest in his name or picture, the Second Circuit's granting of protection to a conmercial interest in one's personality sepa-

game because no competition between owner and broadcaster; court rejectcd property theory). See Comment, 48 Yale L.J. $28 S$ (193S); Note, 35 VA. L. Rev. 254 (1949).

Where a person's performance has "artistic quality." common law coyvright divetrine may give him relief against unauthorized reproduction. See Waring v. Dunlea, $26 \mathrm{~F}$. Supp. 338 (D.N.C. 1939) ; Waring v. W.D.A.S. Broadcasting Station, 327 Pa. 433, 194 Atl. 631 (1937). But once a performer consents to a reproduction, he may be hald to have lost his copyright by "publication" so that he cannot control subscquent use of the regroduction. R.C.A. Mfg. Co. v. Whiteman, 114 F.2d $\$ 6$ (2d Cir. 1940). Sce Solinger, Unauthorized Use of Telecasts, is CoL. L. Rev. S4S (1948).

28. While the right of privacy is considered "waived" when the court feels an individual's privacy interest is outweighed by the public's interest in news or iniormation about his activities, Smith v. Suratt, 7 Alaska 416 (1926); Sidis v. F-R Pub. Curp., 113 F.2d 860 (2d Cir.), cert. denied, 311 U.S. 711 (1940), this "waiver" merely permits news reporting, not advertising, see e.g., Pavesich v. New Eng. Mfut. Life Ins. Co., 122 Ga. 190, 50 S.E. 68 (1905); Foster-Milburn v. Chinn, 134 Ky. 424, 120 S.W. 354 (1909); Pallas v. Crowley, Millner \& Co., 322 Mich. 411, 33 N.W.2d 911 (1948). See Nizer, The Right of Prizacy: A Half Century's Developments, 39 Arrcr. L. Rev. 526, 547 (1941).

However, where a person has sought and received wide publicity, he may be held to have relinquished his right of privacy even for advertising purposes. See cases cited note 22 stpra.

29. The public's interest probably should be deemed paramount in many non-advertising cases. Extending the "right of publicity" to its logical limit would prevent any appropriation of values created by another-a result which may conflict with the policy of federal copyright and patent laws. See, e.g., R.C.A. Mlfg. Co. v. Whiteman, 114 F.2d 86 (2d Cir. 1940) (denying relief to performer against unauthorized distribution of recordings of his performance); Chaffee, Unfair Competition, 53 Hasv. Lo Rvv. 12ig, 1317-20 (1940) ; Zlinkoff, Monopoly zersus Competition: Significant Tresds in Patcnt, Anti-Trust, Tradenark and Unfair Competition Suits, 53 YALE LJ. 514 (1944).

30. See text at note 13 supra. 
rate from a privacy interest is doctrinally important. In applying the right of privacy, courts have confused commercial interests with privacy interests. The result of making one doctrine do the work of two has been inadectuate protection for both these interests in personality. The right of privacy gives inadequate protection to the commercial interest in one's personality because courts have placed upon the right limitations which are appropriate only to the privacy interest. ${ }^{31}$ Similarly, in some states the right of privacy gives inadequate protection even to the privacy interest because courts and legislatures have implied that commercial benefit to the defendant is an element of the cause of action. ${ }^{32}$ If courts wish to protect both interests to at least some extent, they should do so under separate doctrines, so that limitations appropriate to each interest may be imposed. The Haelan case takes a long step in this direction.

JOSEPH R. GRODIN †

31. See cases cited in notes, 7, 8, 22 supra.

32. The right of privacy statutes, patterned after that of New York, note 2 supro, prevent unauthorized use of a person's name or picture only for purposes of "advertising or trade." In interpreting these statutes, courts have been inclined to look to the motives of the user in deciding whether a particular use is primarily for trade or advertising purposes, or for educational or informational purposes. E.g., Callas v. Whisper, 198 Misc. 829, 101 N.Y.S.2d 532 (Sup. Ct. 1950); Kline v. McBride \& Co., 170 Misc. 974, 11 N.Y.S.2d 674 (Sup. Ct. 1939); Lahiri v. Daily Mirror, 162 Misc. 776, 295 N.Y. Supp. 382 (Sup. Ct. 1937). Even in states which recognize the right of privacy at common law the commercial element is sometimes stressed. E.g., Melvin v. Reed, 112 Cal. App. 285, 288, 297 Pac. 91, 93. (1931) ("The right of action accrues only when the publication is made for profit. (This, however, is questioned by some cases)").

† Member of the Class of 1954, Yale Law School. 